\title{
Evaluation of in-Vehicle Phaeton Accidents Admitted to the Emergency Department: A Retrospective Study
}

\author{
Rohat Ak, (1) Nihat Müjdat Hökenek
}

Department of Emergency Medicine, University of Health Sciences, Kartal Dr. Lutfi Kirdar City Hospital, Istanbul, Turkey

\begin{abstract}
Introduction: The aim of this study is to evaluate the traumatic consequences of in-vehicle phaeton accidents.

Methods: The study is a retrospective and observational study. Patients who admitted to the emergency department due to phaeton accidents, in a period of 8 years between 2011 and 2019, in a tertiary university hospital, were included in the study. The data were scanned twice from the hospital automation system. Patients who met the inclusion criteria and did not meet the exclusion criteria were included in the study. Demographic data and injury regions of the patients were examined in the study. Statistical significance was accepted as $p<0.05$.

Results: There were 124 patients included in this study, which 52 were women and 72 were men. Mortality was seen in 35 (28.2\%) patients. In ex cases, the percentage of nasal, subdural, epidural, intraparenchymal, skull fractures, intestinal perforation, intra-abdominal free mai, pelvis, femur, pneumothorax, hemothorax, rib fracture, and soft-tissue injury was found to be higher than the survivor cases $(p<0.05)$.

Discussion and Conclusion: Phaeton accidents are serious injuries that can cause fatal consequences. Mortality rates in these accidents can be reduced through increasing the safety measures integrated into the vehicle.

Keywords: Emergency department; head trauma; phaeton; trauma.
\end{abstract}

A ccidents with horses are injuries that occur with high energy and can have serious consequences ${ }^{[1]}$. Horses generally weigh more than $500 \mathrm{~kg}$ and can strike with a force of more than 1 ton $^{[2]}$. When such a high force and weight are added to a height of $3 \mathrm{~m}$ and a speed of 65 $\mathrm{km} / \mathrm{h}$, the consequences of the trauma created by the accident can be mortal[ ${ }^{[3]}$. The consequences of this situation can lead to serious extremity injuries such as brain, spinal, thoracic, abdominal injuries, and limb loss.

Phaetons have been used as a vehicle for human beings for centuries ${ }^{[4]}$. After the discovery of the wheel in the Bronze Age, a transportation revolution occurred with the invention of phaetons ${ }^{[4]}$. These vehicles, which can travel long distances, were used both in the revival of trade and in wars ${ }^{[4,5]}$. They were used as the main vehicles of transportation in many countries around the world until after the World War II[6].

Although phaetons are generally used for touristic trips in today, they are still used as vehicles in some countries ${ }^{[7]}$. The most important feature that distinguishes phaeton-related accidents from other motor vehicles accidents is that there are at least two living that direct the vehicle. While the vehicles are completely under the control of the drivers in motor accidents, the severity and course of the accident

Correspondence (İletişim): Nihat Müjdat Hökenek, M.D. Saglik Bilimleri Universitesi, Kartal Dr. Lutfi Kirdar Sehir Hastanesi, Acil Tip Klinigi, Istanbul, Turkey

Phone (Telefon): +90 5553201419 E-mail (E-posta): nihathokenek@gmail.com

Submitted Date (Başvuru Tarihi): 06.05.2021 Accepted Date (Kabul Tarihi): 23.05.2021

Copyright 2021 Haydarpaşa Numune Medical Journal

OPEN ACCESS This is an open access article under the CC BY-NC license (http://creativecommons.org/licenses/by-nc/4.0/) 
may change according to the reaction of the horse that in the panic in phaeton accidents. In this case, accidents can be caused by horses being startled, excited, or the equipment failure ${ }^{[8]}$.

There are many studies in the literature that compile horserelated accidents ${ }^{[9,10]}$. Especially, accidents of amateur horse sports or jockeys have been reported ${ }^{[9-11]}$. Likewise, $23 \%$ of the accidents of jockeys in straight races were reported with hospital admissions and $16.67 \%$ of resulted in operation ${ }^{[11]}$. In addition, in horse races, a fall was reported for 1 out of every 250 runs, and injury was reported at a rate of $35 \%$ in falls ${ }^{[9]}$. In the races with hurdles, this rate resulted in one fall in every 20 runs and $20 \%$ injury. These results reveal the seriousness of the accidents. Thus, it is a fact that in professional horse sports accidents, riders are more advantageous than phaeton accidents in terms of preventing mortality and morbidity due to factors such as having protective equipment and being constantly observe by the health team. Accidents caused by these frequently used vehicles for touristic purposes, and the evaluation of their results, can give an idea about the measures to be determined in the accident areas. Predicting the consequences of the accidents caused by these vehicles, which are still actively used in low socioeconomic regions, can contribute to the health infrastructure plan.

We did not find any study evaluating phaeton accidents in the literature. The primary aim of this study is to examine the characteristics and results of in-vehicle phaeton accidents.

\section{Materials and Methods}

\section{Study Design and Selection of Patients}

This study was programmed retrospectively and descriptively in a university hospital. The study included patients brought to the emergency department (ED) by the emergency medical service due to an in-vehicle phaeton accident in the 8 years between 2011 and 2019. The approval was obtained for the study from the local ethics committee of the university (Ethics committee ruling number: 2020/514/171/6). The cases that have the word "phaeton" in the epicrisis were scanned by the emergency service secretary, from the hospital automation system. The epicrisis of all the cases reached later was examined separately by two emergency medicine specialists. The cases that were planned to be excluded were decided in a collective meeting. From the 127 cases that have been reached, the data of three which are a non-vehicle accident (phaeton crash) were excluded, the 124 patients who had a vehicle accident were included in the study. The imaging and examination findings of the cases were recorded in the data form. Later, the images were reexamined by a radiologist, and the findings in the epicrisis and imaging reports were confirmed. Thus, the radiological findings of all patients in the study were confirmed by two radiologists.

Descriptive characteristics of the patients such as age, sex, accident on weekdays/weekends, or day/night were evaluated.

Trauma areas in the body were examined in detail. At this stage, the conditions of following were examined for the face and head: The injuries of frontal, zygoma, mandible, maxilla, nasal bone, skull bone, and the presence bleeding of subdural, epidural, subarachnoid, and intraparenchymal. Spinal injuries were examined as cervical, thoracic, lumbar, and sacral spinal.

\section{Statistical Analysis}

$R$ version 2.15.3 program ( $R$ Core Team, 2013) was performed for the statistical analysis. While reporting the study data, minimum, maximum, mean, standard deviation, median, first quarter, third quarter, frequency, and percentage were used. The compatibility of quantitative data to normal distribution was evaluated by Shapiro-Wilk test and graphical analysis. Mann-Whitney U-test was used for the evaluation of variables that did not show normal distribution between two groups. Pearson's Chi-squared test and Fisher's exact test were used to compare qualitative data. Statistical significance was accepted as $p<0.05$.

\section{Results}

The study was conducted with a total of 124 patients, which 52 were female and 72 were male (Table 1). Mortality was observed in 35 of the patients, the mean age was 37 (21, $66)$ in the group with mortality and $32(21,50)$ in the group with no mortality $(p=0.406)$ (Table 2$)$. There was no statistically significant difference between the groups in terms of whether the accidents were day/night or weekdays/weekends ( $p>0.05)$. After the accident, $22 \%(n=20)$ of all patients were followed up in the intensive care unit (ICU), and mortality was observed in 18 of these 20 patients.

It was found that age, sex, nationality, being on weekends/ weekdays, and being day/night had no effect on mortality ( $p>0.05)$. The hospitalization period of ex cases was found to be longer $(p<0.001)$. It was determined that the ex percentage was higher in cases requiring hospitalization and intensive care $(p<0.001$ and $p<0.001$, respectively). Injury regions and types according to total and mortality are presented in Table 3. 
Table 1. Descriptive characteristics of the study subjects

\begin{tabular}{|c|c|c|}
\hline Variables & Min-Max & Mean \pm SD \\
\hline Age & $1-90$ & $37.98 \pm 24.06$ \\
\hline \multirow[t]{2}{*}{ Duration of the treatment } & $0-31$ & $2.38 \pm 5.24$ \\
\hline & $\mathbf{n}$ & $\%$ \\
\hline \multicolumn{3}{|l|}{ Sex } \\
\hline Female & 52 & 41.9 \\
\hline Male & 72 & 58.1 \\
\hline \multicolumn{3}{|l|}{ Nationality } \\
\hline Foreign & 10 & 8.1 \\
\hline Turkish & 114 & 91.9 \\
\hline \multicolumn{3}{|l|}{ Hospitalization/discharge } \\
\hline Discharge & 79 & 63.7 \\
\hline Hospitalization & 45 & 36.3 \\
\hline \multicolumn{3}{|l|}{ Mortality } \\
\hline Survivor & 89 & 71.8 \\
\hline Ex & 35 & 28.2 \\
\hline \multicolumn{3}{|c|}{ Intensive care unit requirement } \\
\hline No & 104 & 83.9 \\
\hline Yes & 20 & 16.1 \\
\hline \multicolumn{3}{|l|}{ Week day } \\
\hline Weekend & 39 & 31.5 \\
\hline Weekday & 85 & 68.5 \\
\hline \multicolumn{3}{|l|}{ Day/night } \\
\hline Night & 35 & 28.5 \\
\hline Day & 88 & 71.5 \\
\hline
\end{tabular}

n: Number of cases; \%: Percent.

In ex cases, percentages of nasal, subdural, epidural, intraparenchymal, skull fractures, intestinal perforation, intraabdominal free mai, pelvis, femur, pneumothorax, hemothorax, AC contraction, rib fracture, and soft-tissue injury were found to be higher than the survivor cases $(p=0.030$, $p=0.019, p<0.001, p=0.001, p<0.001, p=0.021, p=0.001$, $p=0.006, p=0.011, p=0.006, p=0.006, p=0.005, p=0.001$ ， and $p<0.001$, respectively).

\section{Discussion}

This study is the first study in the literature to examine the demographic data of in-vehicle phaeton accidents. Our aim in the study is to determine the types and consequences of injuries in these accidents admitted to a tertiary emergency department in an 8-year period. In this way, we aim to discuss the measures that can be determined in these vehicles.

In this study, it is remarkable that both cranial, thoracic, and abdominal injuries were serious, especially in accidents that resulted in mortality. This situation can be considered as a natural consequence of the passengers and drivers in the phaeton not using any protective equipment, includ-
Table 2. Comparison of the groups with and without mortality

\begin{tabular}{|c|c|c|c|}
\hline Variables & $\begin{array}{l}\text { Survivor } \\
\text { Median } \\
(\mathbf{Q 1 , Q 3 )}\end{array}$ & $\begin{array}{c}\text { Ex } \\
\text { Median } \\
(\mathbf{Q 1}, \mathbf{Q 3})\end{array}$ & $\mathbf{p}$ \\
\hline Age & $32(21,50)$ & $37(21,66)$ & ${ }^{\mathrm{a}} 0.406$ \\
\hline \multirow[t]{2}{*}{ Duration of the treatment } & $0(0,0)$ & $3(2,5)$ & $a_{<}<0.001^{*}$ \\
\hline & n (\%) & n (\%) & \\
\hline Sex & & & $\mathrm{b}_{0.279}$ \\
\hline Female & $40(76.9)$ & $12(23.1)$ & \\
\hline Male & $49(68.1)$ & $23(31.9)$ & \\
\hline Nationality & & & ${ }^{c} 0.280$ \\
\hline Foreign & $9(90)$ & $1(10)$ & \\
\hline Turkish & $80(70.2)$ & $34(29.8)$ & \\
\hline Hospitalization/discharge & & & $b_{<}<0.001^{*}$ \\
\hline Discharge & $74(93.7)$ & $5(6.3)$ & \\
\hline Hospitalization & $15(33.3)$ & $30(66.7)$ & \\
\hline Intensive care unit requirement & & & $\mathrm{b}_{<}<0.001^{*}$ \\
\hline No & $87(83.7)$ & $17(16.3)$ & \\
\hline Yes & $2(10)$ & $18(90)$ & \\
\hline Week day & & & $\mathrm{b}_{0} 0.665$ \\
\hline Weekend & $29(74.4)$ & $10(25.6)$ & \\
\hline Weekday & $60(70.6)$ & $25(29.4)$ & \\
\hline Day/night & & & $\mathrm{b}_{0} 0.986$ \\
\hline Night & $25(71.4)$ & $10(28.6)$ & \\
\hline Day & 64 (71.9) & $25(28.1)$ & \\
\hline
\end{tabular}

a: Mann-Whitney U-test, results are presented as median (first quarter and third quarter); b: Pearson's Chi-squared test; c: Fisher's exact test; *: $\mathrm{P}<0.05$.

ing seat belts, while driving. Thus, protective equipment is used in almost all motorized transport vehicles. However, there is no protective method or system in these vehicles, which are used for touristic purpose and can reach a speed of approximately $65 \mathrm{~km} / \mathrm{h}^{[3]}$. In areas where phaetons are used for transportation or touristic purposes, this situation can be discussed and safer transportation opportunities can be provided with both legal and technical changes that can be made.

Although studies on horse-related accidents usually have upper limb, lower limb, spinal, and head trauma, it is found that the results were different in our study ${ }^{[12-14]}$. The difference in our study is the severity of the head injury. The clinical course of 25 of 26 patients with skull bone fractures resulted in mortality $(p<0.001)$. Subdural, epidural, and intraparenchymal hemorrhages have also been associated with mortality in phaeton accidents. Even though the phaetons can be as speed as an middle level urban motor vehicle, the severity of the trauma is much more than expected. Therefore, measures can be determined to reduce the severity of the head trauma in-vehicle. In fact, all these results show the necessity of integrating systems such as 
Table 3. Injury distribution by body region

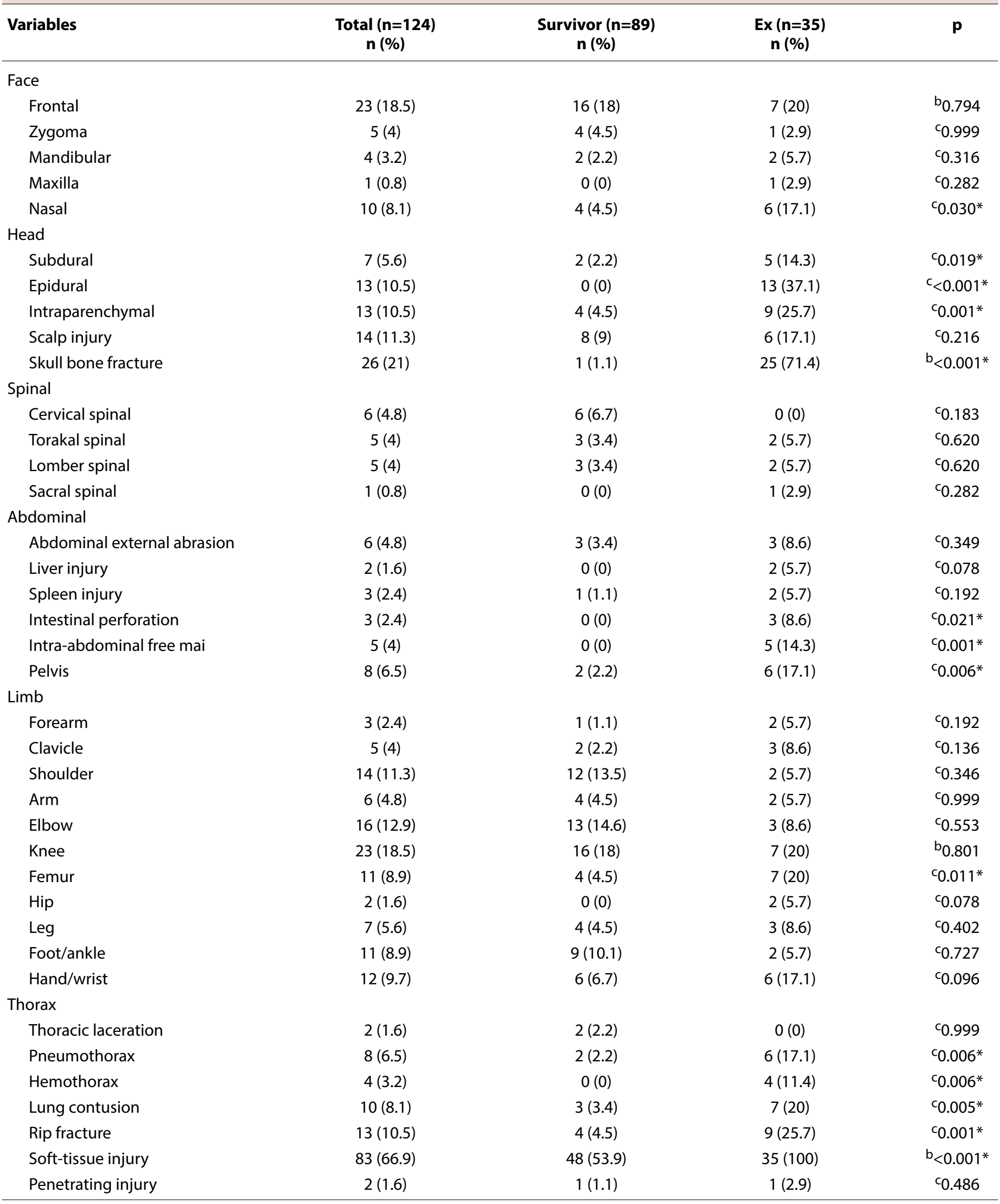

b: Pearson's Chi-squared test; c: Fisher's exact test; ${ }^{*}: \mathrm{P}<0.05$. 
protective equipment against high-energy head trauma or seat belts that will secure the passenger to the vehicle while planning the precautions related to the phaeton ${ }^{[14]}$.

In our study, especially intestinal perforation and pelvic injuries were found to be associated with mortality in injuries caused by phaeton accidents $(p<0.05)$. Although these injuries are seen with a low frequency (3 [2.4\%], 8 [6.5\%]), it should be kept in mind that the consequences may be mortal. Another interesting result of our study is that there is a significant correlation with mortality in patients with free fluid $(5[4 \%])$ in the abdomen $(p<0.05)$. Thus, this finding can be easily detected by ultrasonography that can be performed at bedside in ED. When emergency physicians determine intra-abdominal free fluid in such patients, it should be kept in mind that the patient's clinic may deteriorate rapidly and the prognosis may result in mortality.

Almost all types of thoracic injuries were determined to be significantly associated with mortality $(p<0.05)$. As a natural consequence of the design of the phaeton, the absence of any mechanism to prevent the casualty moving away from the vehicle may have caused this situation.

In the area where the study conducted, phaetons are used for touristic purposes. When the accidents are evaluated according to the frequency of the weekdays and weekends, it has been determined that there are more frequent accidents on the weekends ( $p>0.05$ ). This result may suggest that traffic density is not related to an accident.

Patients who are hospitalized due to phaeton accidents have a poor prognosis in the future. It may be characteristic of accidents that do not have a gray zone and result in either mortality or discharge. According to the results of the study, mortality was found to be high in patients who were hospitalized in the ED or ICU and/or the length of staying was higher $(p<0.001, p<0.001$, and $p<0.001)$. This result supports the severity of the injuries.

If the studies on this subject are planned prospectively and consideration of the geographical features of the location of the accident, the number of passengers in the vehicle, and the presence of security equipment, then it can contribute more to the literature.

\section{Conclusion}

In-vehicle accidents with phaeton can cause serious injuries. Safety measures such as seat belts and head protection equipment to be integrated into the vehicle can help reduce mortality rates in these accidents.

Ethics Committee Approval: The Health Sciences University Kartal Dr. Lutfi Kırdar City Hospital Clinical Research Ethics Committee granted approval for this study (date: 12.02.2020, number: 2020/514/171/6).
Peer-review: Externally peer-reviewed.

Authorship Contributions: Concept: R.A., N.M.H.; Design: R.A., N.M.H.; Data Collection or Processing: R.A., N.M.H.; Analysis or Interpretation: R.A., N.M.H.; Literature Search: R.A., N.M.H.; Writing: R.A., N.M.H.

Conflict of Interest: None declared.

Financial Disclosure: The authors declared that this study received no financial support.

\section{References}

1. Papachristos A, Edwards E, Dowrick A, Gosling C. A description of the severity of equestrian-related injuries (ERIs) using clinical parameters and patient-reported outcomes. Injury 2014;45:1484-7. [CrossRef]

2. Nelson DE, Bixby-Hammett D. Equestrian injuries in children and young adults. Am J Dis Child 1992;146:611-4. [CrossRef]

3. Sorli JM. Equestrian injuries: A five year review of hospital admissions in British Columbia, Canada. Injury Prev 2000;6:59-61.

4. Bokonyi S. History of horse domestication. Anim Genet Resour Inf 1987;6:29-34. [CrossRef]

5. Thompson F. Nineteenth-century horse sense. Econ Hist Rev 1976;29:60-81. [CrossRef]

6. Zvirgzdinš I. Production of Horse-Drawn Carriages in Latvia in the $20^{\text {th }}$ Century. Vol. 4. History of Engineering Sciences and Institutions of Higher Education; 2020. p. 9-30. [CrossRef]

7. Nigatu A, Abebaw Z, editors. Socioeconomic Impact of Epizootic Lymphangitis (EL) on Horse-drawn Taxi Business in Central Ethiopia. The $6^{\text {th }}$ International Colloquium on Working Equids; 2010.

8. O'Connor S, Hitchens PL, Fortington LV. Hospital-treated injuries from horse riding in Victoria, Australia: time to refocus on injury prevention? BMJ Open Sport Exerc Med 2018;4:e000321. [CrossRef]

9. O'Connor S, Warrington G, McGoldrick A, Cullen S. Epidemiology of injury due to race-day jockey falls in professional flat and jump horse racing in Ireland, 2011-2015. J Athl Train 2017;52:1140-6. [CrossRef]

10. O'Connor S, Warrington G, Mb AM, Cullen S. A 9-year epidemiologic study (2007-2015) on race-day jockey fall and injury incidence in amateur Irish horse racing. J Athl Train 2018;53:950-5. [CrossRef]

11. O'Connor S, Warrington G, O'Brien S, McDermott E, McGoldrick A, Pugh J, et al. Injuries outside of horseracing: Is it time to focus on injury prevention of jockeys outside of races? Phys Sportsmed 2021;49:45-50. [CrossRef]

12. Altgärde J, Redéen S, Hilding N, Drott P. Horse-related trauma in children and adults during a two year period. Scand J Trauma Resusc Emer Med 2014;22:1-5. [CrossRef]

13. Loder RT. The demographics of equestrian-related injuries in the United States: Injury patterns, orthopedic specific injuries, and avenues for injury prevention. J Trauma Acute Care Surg 2008;65:447-60. [CrossRef]

14. Whitlock MR. Injuries to riders in the cross country phase of eventing: The importance of protective equipment. $\mathrm{Br}$ J Sports Med 1999;33:212-4. [CrossRef] 